\title{
AMFR wt Allele
}

National Cancer Institute

\section{Source}

National Cancer Institute. AMFR wt Allele. NCI Thesaurus. Code C51346.

Human AMFR wild-type allele is located within 16q21 and is approximately $64 \mathrm{~kb}$ in length. This allele, which encodes E3 ubiquitin-protein ligase AMFR protein, plays a role in cellular motility. 